\title{
The First Salmonella Enteritidis Phage Type 1 Infection of a Commercial Layer Flock in Finland
}

\author{
By T. M.-L. Johansson ${ }^{1}$, R. Schildt ${ }^{2}$, S. Ali-Yrkkö ${ }^{3}$, A. Siitonen $^{4}$ and R. L. Maijala ${ }^{5}$
}

${ }^{1}$ Department of Food Microbiology, ${ }^{2}$ Department of Bacteriology, ${ }^{3}$ Turku Regional Laboratory, ${ }^{5}$ Department of
Pathology and Field Extension, National Veterinary and Food Research Institute, Helsınk1, and ${ }^{4}$ Laboratory of
Enteric Pathogens, National Public Health Institute, Helsink1, Finland.

Johansson, T.M.-L., R. Schildt, S. Ali-Yrkkö, A. Siitonen and R. L. Maijala: The first Salmonella Enteritidis phage type 1 infection of a commercial layer flock in Finland. Acta vet. scand. 1996, 37, 471-480. - The first Salmonella Enterttidls phage type (PT) 1 infection in a commercial layer flock of 2700 birds in Finland occurred in 1995. All the birds were ordered to be k1lled, the eggs to be destroyed and access to the layer house was denied in order to prevent spread of the infection. Ninety one commercial layers, 61 replacement pullets and 1062 eggs were collected for the analyses. The total infection level of the flock was $8 \%$, concentrated on the 2 older age groups. $S$. Enteritidis PT1 was isolated from livers (5\%), ovaries (2\%) and from caeca (3\%), of which 2 positive samples were detected with pre-enrichment and 3 without pre-enrichment by cultivation Rambach agar. Eight \% of 105 pooled egg samples were positıve, of which 2 were detected only from contents and 3 only from shells indicating both oviductal and faecal contamination routes of eggs. The results support the use of the extended sampling procedure in poultry flocks suspected of human food-borne Salmonella outbreaks of invasive serotypes, including not only faecal but also environmental, organ, blood and/or egg samples.

caeca; livers; ovaries; eggs.

\section{Introduction}

During the past decade, infection of commercial layers with Salmonella Enteritidis and the resultant contamination of eggs have caused a marked increase in human salmonellosis in many countries (Rodrigue et al. 1990). Although there are over 30 phage types of $S$. Enteritidis, only a few of them have been important in food-borne infections (Humphrey 1994). In Western Europe, PT4 is the most prevalent phage type, whereas PT8 is found in North America (Khakhria et al. 1991, Mason 1994) and PT1 e.g. in Poland, Russia and Estonia (Hansenson et al. 1992).

$S$. Enteritidis is a so-called invasive serotype for poultry. This means that it has the potential for transovarian transmission, leading to the internal contamination of eggs (Humphrey et al. 1989b). Several reports on experimental infections of laying hens by $S$. Enteritidis, especially PT4, have been published, but only a few on naturally infected commercial layer flocks (Hopper \& Mawer 1988, Humphrey et al. $1989 \mathrm{~b})$. Several studies have also been performed on the growth, penetration and detection of PT4 in naturally and artificially contaminated eggs (Humphrey 1989a, Humphrey et al. 1989b, Humphrey \& Whitehead 1993, Schoeni et al. 1995). However, no such reports are available for PT1, because it has had only a minor role among reported $S$. Enteritidis infections. 
During August-October 1995 a food-borne outbreak involving about 150 persons occurred in southwestern Finland (unpublished results). The causative agent was identified as $S$. Enteritidis PT1 by the National Public Health Institute of Finland. The same phage type had caused at least 8 outbreaks from unknown sources involving over 400 people in southwestern Finland during the 1990s. In addition to these outbreaks only one other $S$. Enteritidis PT1 infection has been reported in Finland (unpublished result). According to molecular biological analyses all the 8 outbreaks were caused by the same PT1 strain, which however differed slightly from the PT1 prevalent in eastern Europe. Epidemiological studies were indicative of the eggs produced by a poultry farm in southwestern Finland. However, despite several faecal samplings made in this farm during the 1990s, S. Enteritidis could not be isolated. In September 1995 five commercial layers of the suspect poultry farm were killed and examined for Salmonella. $S$. Enteritidis PT1 was isolated from one caecal sample. This was the first case in which $S$. Enteritidis PT1 was detected in a Finnish commercial layer flock.

Immediately after the $S$. Enteritidis isolation the Veterinary and Food Department of the Ministry of Agriculture and Forestry ordered all the birds to be killed, the eggs to be destroyed and access to the layer house to be denied in order to prevent spreading of the infection. The National Food Administration ordered the withdrawal and destruction of the eggs originating from this layer house and marketed to some caterings, bakeries and one retail store in 3 surrounding municipalities.

This work was performed in order to study the infection level of $S$. Enteritidis PT1 in this commercial layer flock. The different isolation methods for Salmonella from caecal contents, with or without pre-enrichment and different selective plating media, were also studied.

\section{Materials and methods}

\section{Birds}

A total of 152 birds out of 2700 (5.6\%), including both commercial layers and replacement pullets, were autopsied (Table 1). The caeca were transferred into Petri dishes, ovaries and livers into separate stomacher bags. These samples were analysed for Salmonella.

\section{Eggs}

A total of 1062 eggs were collected from the poultry house during a period of 14 days. Eight hundred sixty two of the eggs originated from commercial layers and 200 from replacement pullets. One thousand of the eggs were stored at room temperature $\left(22-24^{\circ} \mathrm{C}\right)$ for the first 17 days (Humphrey \& Whitehead 1993) and at $7.5^{\circ} \mathrm{C}$ for the last 5 days before analyses of $\mathrm{Sal}$ monella. Additionally, 62 of the eggs of commercial layers were stored at $100 \%$ relative humidity (rh) at $22-24^{\circ} \mathrm{C}$ for the first 14 days.

Five hundred thirty one of the eggs had been washed by the farmer. The other 531 eggs were unwashed and the shells were contaminated with faeces. The eggs were candled before microbiological analyses to reveal spoilage and cracks. All the eggs had a poor shell quality (rough-surfaced, splashed and/or wrinkled) and therefore no disinfection was used prior to microbiological analyses. Twelve of the eggs (11 washed and 1 unwashed) stored at $100 \%$ rh were found to be spoiled and were rejected.

\section{Pathological analyses}

After killing, the birds were necropsied within a few hours and examined for gross lesions.

\section{Microbiological media and reagents}

The media supplied by LabM (Bury, England) were: buffered peptone water (BPW; LAB46), Rappaport-Vassiliadis broth (RV; LAB86), brilliant-green phenol red agar (BGA; LAB34), xylose-lysine decarboxylase agar (XLD; 
Table 1. Detection of gross lesions and $S$ Enterittds PT1 in a commercial layer flock

\begin{tabular}{|c|c|c|c|c|c|c|c|}
\hline \multirow{2}{*}{ Type of birds } & \multirow{2}{*}{ Age group } & \multirow{2}{*}{$\begin{array}{c}\text { Age } \\
\text { (weeks) }\end{array}$} & \multicolumn{2}{|c|}{ Number of birds } & \multirow{2}{*}{$\begin{array}{c}\text { Egg production } \\
(\%)\end{array}$} & \multirow{2}{*}{$\begin{array}{l}\text { Gross lesions } \\
(\%)\end{array}$} & \multirow{2}{*}{$\begin{array}{l}\text { Salmonella positive } \\
(\%)\end{array}$} \\
\hline & & & in flock & $\overline{\text { sampled }}$ & & & \\
\hline Commercial layers & I & 61 & 500 & 30 & 87 & 13 & 0 \\
\hline Commercial layers & II & 74 & 500 & 28 & 57 & 43 & 18 \\
\hline Commercial layers & III & 88 & 500 & 33 & 82 & 18 & 18 \\
\hline All layers & I-III & $61-88$ & 1500 & 91 & 75 & 24 & 12 \\
\hline Replacement pullets & & 18 and 21 & 1200 & 61 & 26 & 0 & 0 \\
\hline All birds & & & 2700 & 152 & 56 & 15 & 7 \\
\hline
\end{tabular}

LAB32), triple sugar iron agar (TSI; LAB53) and urea agar (LAB130). Önöz (15034) (Önöz \& Hoffman 1978), bromothymolblue-lactose (BROLAC; 1639) and Rambach (7500.0002) agars were supplied by Merck (Darmstadt, Germany) and slide agar from Orion Diagnostica (Espoo, Finland). Ferrous(II)sulphate $\left(\mathrm{FeSO}_{4} \times 7 \mathrm{H}_{2} \mathrm{O}\right)$ was obtained from Merck (3965), ANISalmonella test from ANI Biotech Oy (Helsinki, Finland) and the Salmonella typing sera from Behringwerke AG (Marburg, Germany).

\section{Microbiological analyses of organ samples}

The microbiological analyses of Salmonella from both organ samples and eggs were based on the method of the Nordic Committee on Food Analysis (Anon. 1991).

The contents of caeca were analysed twice: immediately after the birds were autopsied (I isolation) and 4 weeks later (II isolation), after storage in a freezer at $-18^{\circ} \mathrm{C}$. Each isolation (I and II) was performed with and without pre-enrichment.

In the pre-enrichment procedure $0.5-1.0 \mathrm{~g}$ of caecal contents were transferred by a loop into $\mathrm{BPW}(9 \mathrm{ml})$, which was then incubated at $37^{\circ} \mathrm{C}$ for $24 \mathrm{~h} .0 .1 \mathrm{ml}$ of this pre-enrichment culture was further transferred to $\mathrm{RV}(10 \mathrm{ml})$ and was incubated at $41.5^{\circ} \mathrm{C}$ for $24 \mathrm{~h}$. Analysis without pre-enrichment was performed by enriching a loopful (about $0.5 \mathrm{~g}$ ) of caecal contents in RV $(10 \mathrm{ml})$ at $41.5^{\circ} \mathrm{C}$ for $24 \mathrm{~h}$. In both procedures $0.1 \mathrm{ml}$ of $\mathrm{RV}$ was streaked in the first isolation (I) onto BROLAC and Önöz agar plates. In the second isolation 4 different selective media (BGA, XLD, Önöz, Rambach) were used in both procedures, and additionally Orion slide agar was also used for the procedure without pre-enrichment. The plates were incubated at $37^{\circ} \mathrm{C}$ for $24 \mathrm{~h}$.

All the livers (30-60 g) and ovaries (about $60 \mathrm{~g}$ ) of commercial layers were stomachered in 200 $\mathrm{ml} \mathrm{BPW}$ and ovaries (2-6 g) of replacement pullets in $50 \mathrm{ml} \mathrm{BPW}$ for $30 \mathrm{sec}$ and incubated at $37^{\circ} \mathrm{C}$ for $24 \mathrm{~h} .0 .1 \mathrm{ml}$ aliquots of these cultures were further enriched in RV and streaked onto XLD and Önöz media, which were incubated at $37^{\circ} \mathrm{C}$, XLD for $24 \mathrm{~h}$ and Önöz for $48 \mathrm{~h}$.

\section{Microbiological analyses of eggs}

Ten eggs were pooled together to form 2 samples: contents and shells. This resulted in 105 pooled samples of contents and 105 pooled samples of shells. Sterile disposable gloves were used while cracking the eggs and were changed between each pooled sample. The eggs were broken by cracking the shells against the edge of a basket covered with a sterile stomacher bag, which was changed between each pooled sample as well. The contents and shells 
were each transferred into their own stomacher bags. BPW supplemented with ferrous(II)sulphate $(35 \mathrm{mg} / \mathrm{l})$ (Gast 1993) was added into the bags to obtain a ratio of $1: 1$ sample to BPW. This meant $500 \mathrm{ml} \mathrm{BPW}$ for the contents and $100 \mathrm{ml}$ for the shells (Wray \& Davies 1994). The samples of the contents were homogenized in the stomacher for $30 \mathrm{sec}$. About $50 \mathrm{ml} \mathrm{sam}$ ples of these suspensions were transferred into tubes for most probable number (MPN) analyses and were stored in a freezer at $-18^{\circ} \mathrm{C}$. Shells were crushed by hand. The pre-enrichment broths and RV were incubated as for the organ samples. XLD, Önöz and Orion slide agar were used for selective plating.

The MPN procedure was performed with the pooled samples of egg contents from which $S$. Enteritidis PT1 was detected. Three dilutions with 5 replicates were analysed, which resulted in $5 \times 4 \mathrm{ml}, 5 \times 0.4 \mathrm{ml}$ and $5 \times 0.04 \mathrm{ml}$ of undiluted contents. Pre-enrichment was performed in BPW and enrichment in RV. XLD and Önöz were used as solid selective media.

\section{Confirmation of Salmonella}

2-4 typical or suspect colonies from each plate were confirmed by culturing on TSI and urea agars. Pure cultures were made on BROLACagar. Presumptive serological confirmation was performed with the ANI Salmonella test. The positive isolates were serotyped according to the Kauffmann-White Scheme. Phage typing was performed at the National Public Health Institute using the Collindale system (Ward et al. 1987).

\section{Results}

Birds

$S$. Enteritidis PT1 was detected in 11 of 152 birds (7\%). All of the positive birds were older commercial layers and 10 of them were in full lay (Table 1). S. Enteritidis PT1 was detected in
7 (5\%) liver samples (Table 2). In 3 of these birds with positive livers the ovaries were also salmonella-positive (2\%). In the first isolation Salmonella could not be detected in any of the caeca. However, in the second isolation the caecal samples of 5 birds were found to be salmonella-positive ( 2 birds by the procedure with pre-enrichment and 3 birds without pre-enrichment), of which one was detected to be liver positive as well. The use of Rambach agar revealed all the 5 positive caecal samples (Table 2).

During necropsy peritonitis, salphingitis, white spots in the liver or ovary, necrotic foci in the liver, deformed or discoloured ovaries and airsac infection were detected as gross lesions (Table 1). Additionally, persistent cystic right oviduct was seen in $3 \%, 32 \%$ and $9 \%$ of the commercial layers of the age groups I, II and III, respectively. Leiomyoma of the mesosalpinx was detected in one hen of the age group III. There were no correlations between the percentage or the type of gross lesions and the percentage of Salmonella detected in different groups of commercial layers. No gross pathological changes were observed in the replacement pullets.

\section{Eggs}

Eight (8\%) of 105 pooled egg samples were salmonella-positive (Table 3). Of these 6 originated from commercial layers and 2 from replacement pullets. Two of the positive samples were positive only in contents. All the shell positive samples of washed eggs (3) were also positive in contents, whereas none of the shell positive samples of unwashed eggs (3) were contents positive. All the pooled samples of the eggs stored at $100 \%$ humidity were negative. The cell densities of the positive contents varied from $<2.5$ to $<25 \mathrm{MPN} / \mathrm{egg}$ in 2 samples and from 2.5 to 25 , from 150 to 1500 and from 450 to $4500 \mathrm{MPN} / \mathrm{egg}$ in the other 3 samples de- 
Table 2. Isolation of $S$ Enteritidis PT1 from organ samples of commercial layers (1-91) and replacement pullets (92-152).

\begin{tabular}{|c|c|c|c|c|c|c|c|c|c|c|c|c|c|}
\hline \multirow[t]{3}{*}{ Number } & \multirow{3}{*}{$\begin{array}{c}\text { Liver } \\
\text { BPW \& RV } \\
\text { XLD \& Ò }\end{array}$} & \multirow{3}{*}{$\begin{array}{l}\text { Ovaries } \\
\text { BPW \& RV } \\
\text { XLD \& Ó }\end{array}$} & \multicolumn{2}{|c|}{$\begin{array}{l}\text { Caecal contents, } \\
\text { first isolation }\end{array}$} & \multicolumn{9}{|c|}{ Caecal contents, second isolation } \\
\hline & & & \multirow{2}{*}{$\begin{array}{c}\text { BPW \& RV } \\
\text { BR \& O }\end{array}$} & \multirow{2}{*}{$\begin{array}{c}\mathrm{RV} \\
\mathrm{BR} \& \mathrm{O}\end{array}$} & \multicolumn{4}{|c|}{ BPW \& RV } & \multicolumn{5}{|c|}{ RV } \\
\hline & & & & & $\overline{\mathrm{BGA}}$ & XLD & $\dot{0}$ & $\mathrm{R}$ & BGA & XLD & 0 & $R$ & $\mathrm{O}$ \\
\hline 1 & + & + & - & - & - & - & - & - & - & - & - & - & - \\
\hline 2 & + & + & - & - & - & - & - & - & - & - & - & - & - \\
\hline 3 & + & + & - & - & - & - & - & - & - & - & - & - & - \\
\hline 4 & + & - & - & - & - & - & - & - & - & - & - & - & - \\
\hline 5 & + & - & - & - & - & - & - & - & - & - & - & - & - \\
\hline 6 & + & - & - & - & - & - & - & - & - & - & - & - & - \\
\hline 7 & + & - & - & - & - & - & - & - & + & + & + & + & + \\
\hline 8 & - & - & - & - & - & - & - & - & + & - & + & + & - \\
\hline 9 & - & - & - & - & - & - & - & - & - & + & + & + & - \\
\hline 10 & - & - & - & - & - & - & - & + & - & - & - & - & - \\
\hline 11 & - & - & - & - & - & - & - & + & - & - & - & - & - \\
\hline $12-91$ & - & - & - & - & - & - & - & - & - & - & - & - & - \\
\hline $92-152$ & - & - & - & - & - & - & - & - & - & - & - & - & - \\
\hline
\end{tabular}

$\mathrm{BPW}=$ pre-enrıchment in buffered peptone water, $\mathrm{RV}=$ enrichment in Rappaport-Vassiliadis medium, $\mathrm{BR}=$ bromthymolblue-lactose, $\mathrm{BGA}=$ brilliant-green phenol red agar, $\mathrm{XLD}=$ xylose-lysine decarboxylase agar, $\mathrm{O}=$ Önöz agar, $\mathrm{R}=$ Rambach agar, $\mathrm{O}=$ Orion slıde agar, $+=$ detected, $-=$ not detected.

pending on the numbers of positive eggs in pooled samples.

Both XLD and Orion slide agar detected all the 11 positive samples of the 210 pooled samples of contents and shells. Önöz gave 1 false negative. If typical reactions in the tests with TSI, urea and BROLAC and agglutination in the ANItest but a negative result by serotyping is counted as false positive, XLD gave 6, Önöz 1 and Orion slide agar no false positives.

\section{Discussion}

In the present study the infection level of the commercial layer flock by $S$. Enteritidis PT1 was low (7\%) compared to that in a case described by Hopper \& Mawer (1988), who reported $26 \%$ of the birds of a commercial layer flock to be positive for $S$. Enteritidis PT4. This may due to differences in the infection or in the phage type. However, the sampling rate was higher in the present work (152 birds out of 2700) than in the study of Hopper \& Mawer (50 birds out of 60000) (1988). They also studied birds, which had died after infection, whereas in the present work Salmonella was detected from freshly killed birds. Poppe (1994) reported infection levels of $1.3 \%$ and $16 \%$ in 2 flocks infected with $S$. Enteritidis PT13. Significant differences between $S$. Enteritidis strains, isolates or phage types in intestinal colonization, faecal shedding and invasion to internal organs and isolation frequences have been reported. These varying results may also be due to the differences in detection and inoculation methods, doses or ages of birds (Gast 1994). All of the salmonella-positive birds (11) originated from the 2 older age groups. This conforms with the study of Humphrey et al. (1991a), in which prolonged faecal carriage of S. Enteritidis PT4 was observed in older (52 weeks old) specific pathogen free (SPF) White 
Table 3. Detection of $S$. Enteritidls PT1 in eggs.

\begin{tabular}{lcccccc}
\hline \multirow{2}{*}{ Type of birds } & Washing & $\begin{array}{c}\text { Number of } \\
\text { pooled samples }\end{array}$ & \multicolumn{2}{c}{ S enteritids PT1 detected in } & Salmonella \\
\cline { 4 - 5 } & & Contents & Shells & Contents and shells & positive \\
\hline Commercial layers & No & 53 & 1 & 3 & 0 & $8 \%$ \\
Commercial layers & Yes & 32 & 1 & 0 & 1 & $6 \%$ \\
Replacement pullets & Yes & 20 & 0 & 0 & 2 & $10 \%$ \\
Total & & 105 & 2 & 3 & 3 & $8 \%$ \\
\hline
\end{tabular}

Leghorn hens compared to younger birds (20 weeks old). The earlier studies of Humphrey et al. (1989a) with commercial laying flocks containing birds of different age groups also support this result.

Because of the pooling, the exact contamination level of eggs cannot be determined, but it lies within the range $0.8-8 \%$. Various infection levels of $S$. Enteritidis PT4, such as $1.1 \%$ of 451 eggs, $10.3 \%$ of 68 eggs and $1.9 \%$ of 1952 eggs (from shells and contents) laid by naturally infected flocks have been reported (Humphrey et al. 1989b, 1991b).

Two of the salmonella-positive pooled egg samples were detected only from the contents $(0.2-2 \%)$. This conforms with the results of large-scale studies with naturally infected commercial laying flocks (Humphrey et al. 1991b). These studies showed that on average $0.6 \%$ of eggs from $S$. Enteritidis positive flocks have salmonella-positive contents. Humphrey et al. (1989b) studied naturally infected birds and reported that the production of contents-positive eggs per bird was constant (approximately 1.5$2.0 \%$ ). This conforms with the results of the present study, in which $S$. Enteritidis PT1 was detected from 11 commercial layers. If all the 10 of these birds which were in full lay would have laid one egg per day, a total of 140 eggs would have been produced during 14 days. 1.5$2.0 \%$ would give $2-3$ contents-positive eggs In fact, 2 pooled samples of contents were positive and one pooled sample was positive from both contents and shells of commercial layers. In the present study the MPN-values $(<2.5-<25$ MPN/egg and 450-4500 MPN/egg) of the 2 contents-positive egg samples of 3-5 weeks age indicate that the contamination site might have been albumen, which in the case of intact eggs usually means infection in the upper oviduct (Humphrey et al. 1991b). Oviducts were not analysed, but the number of positive samples of ovaries $(5 / 152)$ reflects the infection of reproductive tissues.

The number of egg samples positive in both contents and shells (0.3-3\%) was high compared to the result of Humphrey et al. (1991b). They detected only one egg out of 38 positives to be positive in both contents and shells, and concluded that there is no association between shell and contents contamination of intact shell eggs naturally contaminated with $S$. Enteritidis (Humphrey 1994). However, Schoeni et al. (1995) showed for artificially contaminated eggs that $S$. Enteritidis added to sterilized faeces on the shell surface penetrated the shell in 3 days at $25^{\circ} \mathrm{C}$. In the present study the eggs were of poor shell quality, faecally contaminated and stored at 2 different temperatures for a total of 21 days. Furthermore, the 3 pooled egg samples which were both contents- and shell-positive, originated from a group of eggs washed by the farmer. According to Moats (1978) washing enhances the penetration of faecal material into the eggs. On this basis the faecal contamination route might be suspected 
in the case of these 3 pooled egg samples, positive in both contents and shells.

Two samples of pooled eggs originating from replacement pullets were detected as positive, although $S$. Enteritidis PT1 could not be isolated from the organs of replacement pullets. This result conforms with the studies of Humphrey et al. (1991a, 1989a), who detected that 18-20 weeks old birds, artificially contaminated by $S$. Enteritidis PT4, layed contaminated eggs (positive either in shells or contents) although faecal carriage was not detected and the birds were largely clinically unaffected. They could not isolate Salmonella from organ samples when the birds were killed. These observations indicate that the eggs of replacement pullets might be contaminated either by reproductive tissues or by faeces, although Salmonella was not detected from the flock possibly because of the low infection level. In the present study, although these positive egg samples were positive in both shells and contents, the faecal contamination route was more probable. Furthermore the 3 pooled egg samples from commercial layers which were positive only in shells indicated the faecal contamination route, which was confirmed by the 5 caecal samples detected to be positive.

In our study the caeca were analysed twice and in both isolations not only by direct enrichment in RV but also using pre-enrichment. However, the first isolation with 2 selective plating media failed to reveal the 5 positives, which were detected in the second isolation using 2 procedures with 4-5 selective plating media. Two of the 5 positive results, which were obtained by pre-enrichment, were based on one typical colony on Rambach agar plates. This indicates that the numbers of salmonella in caeca were low and that the organisms were probably unevenly distributed in the contents. Therefore special attention must be paid to the sampling method. The whole caecum must be cut open and the sample of 0.5-1.0 g collected from the whole area in order to ensure detection.

One purpose of this study was to compare the isolation methods of Salmonella with and without pre-enrichment for analyses of caeca. The infection level of the flock was low and therefore conclusions cannot be made on the superiority of either of the procedures. It might be supposed that faeces of sick animals are heavily contaminated and then Salmonella is easily isolated without pre-enrichment, but it is not necessarily so in the case of carriers without symptoms.

Caeca of poultry are rich in Proteus species, which interfere with the detection of Salmonella. The correct choice of solid selective media is therefore very important. BROLAC could not be used because of swarming of Proteus, and BGA promotes the growth of Salmonellalike colonies which prove to be negative in biochemical confirmation. Rambach agar detected all the positive caecal samples and was the only medium which detected the 2 positives found by pre-enrichment. This medium also prevents the swarming of Proteus as efficiently as Önöz. Rambach has proved to be successful in the detection of Salmonella species other than $S$. Typhi also in other studies (Garrick \& Smith 1994, Manafi \& Sommer 1992). Önöz has been widely used for both faecal samples and foods in Finland for many years (Johansson \& Hirn 1992, Hirn et al. 1992) and it performed well in the analyses of eggs, as did XLD and Orion slide agar. It is rather selective and rarely gives false positive results. Orion slide agar was in the shape of a slide and therefore the surface available for spreading an inoculum was too small to obtain separate colonies, which decreases its performance. In the future when it is available as plates, its performance could be reevaluated. However, it detected all the positive egg samples, with no false negatives or positives. 
The surveillance for Salmonella of commercial layer and broiler flocks is usually based on the analysis of faecal samples. However, faecal sampling had failed to detect $S$. Enteritidis PT1 infection in this layer flock despite efforts made over several years. Neither did the first isolation detect Salmonella in the caeca of 152 freshly killed birds. These difficulties can partly be explained by the low level of infection of the birds. Additionally, faecal shedding may be normally absent and evoked in some cases e.g. by stress (Shivaprasad et al. 1990). Therefore these results indicate the need for extended sampling procedures in poultry flocks to survey the risk for human food-borne Salmonella infections. These samples should not only include faecal samples but also environmental, organ and/or blood samples. The collection of eggs for several weeks and the study of pooled egg samples could be a practical sampling method for suspected flocks of commercial layers.

\section{Acknowledgements}

The authors thank DVM Mattı Salmela for his participation in the practical work. The technical assistance of the laboratory personnel of the Departments of $\mathrm{Pa}$ thology and Field Extension, Bacteriology, Food M1crobiology and Turku Regional Laboratory is gratefully acknowledged.

\section{References}

Anonymous: Nordic Committee on Food Analysis (NMKL). Salmonella bacteria. Detection in Foods. 1991, Ref. 71-1991; 9 pp.

Garrick RC, Smith AD: Evaluation of Rambach agar for the differentiation of species from other $E n$ terobacteriaceae. Letters Appl. Microbiol. 1994, 18, 187-189.

Gast RK: Recovery of Salmonella enteritudis from inoculated pools of egg contents. J. Food Protect. $1993,56,21-24$.

Gast RK: Understanding Salmonella enterttidis in laying chickens: the contributions of experimental infections. Int. J. Food Microbiol. 1994, 21, 107-116.
Hansenson LB, Kaftyreva L, Laszlo VG, Woitenkova E, Nesterova M: Epidemiological and microbiological data on Salmonella enteritidis. Acta Microbiologica Hungarica 1992, 39, 31-39

Hirn J, Nurmı E, Johansson T, Nuotıo L $\cdot$ Long-term experience with competitive exclusion and salmonellas in Finland. Int. J. Food Microbiol. 1992, 15, 281-285.

Hopper $S A$, Mawer $S$. Salmonella enteritidis in a commercial layer flock. Vet. Rec. 1988, 123, 351.

Humphrey TJ. Contamınation of egg shell and contents with Salmonella enteritidls A review. Int. J. Food Microbiol. 1994, 21, 31-40.

Humphrey TJ, Baskerville A, Chart H, Rowe B: Infection of egg-laying hens with Salmonella enterttidis PT4 by oral challenge. Vet. Rec. 1989a, 125, 531-532.

Humphrey TJ, Baskerville A, Mawer S, Rowe B, Hopper $S$ Salmonella enteritidis phage type 4 from the contents of intact eggs: A study involving naturally infected hens. Epidemiol. Infect. 1989b, 103, 415-423.

Humphrey TJ, Chart H, Baskerville A, Rowe B. The influence of age on the response of SFP hens to infection with Salmonella enteritidis PT4. Epidemiol. Infect. 1991a, 106, 33-43.

Humphrey TJ, Whitehead A. Egg age and the growth of Salmonella enteritidis PT4 in egg contents. Epidemiol. Infect. 1993, 111, 209-219.

Humphrey TJ, Whitehead A, Gawler AHL, Henley A, Rowe B. Numbers of Salmonella enteritidis in the contents of naturally contaminated hens' eggs. Epidemiol. Infect. 1991b, 106, 489-496.

Johansson T, Hirn J: Comparıson of DNA-hybridization, ELISA and culturing methods for detection of Salmonella and Listeria in deep-frozen broiler carcasses. In: Schwarzwer Chr, Mulder RWAW, (eds.): Proceedings 6'th meetıng on Detection Methods and Sampling Plans for Pathogens in Poultry. Grub: FLAIR No. 6/COST No. 106, 1992, 71-78.

Khakhria R, Duck D, Lior H: Distribution of Salmonella enterttidis phage type in Canada. Epidemiol. Infect. 1991, 106, 25-32.

Manafi M, Sommer R: Comparison of 3 rapid screening methods for Salmonella spp.: 'MUCAP Test, MicroScreen ${ }^{\circledR}$ Latex and Rambach agar', Letters Appl. Microbiol. 1992, 14, 163-166.

Mason J: Salmonella enteritidis control programs in the United States. Int. J. Food Microbiol. 1994, $21,155-169$. 
Moats WA: Egg washing - A review. J. Food Prot. 1978, 41, 919-925.

Önöz E, Hoffman $K$ : Erfahrungen mit einem neuen Nährboden fÿr die Salmonella-Diagnostık. (Experience with a new culture medium for Salmonella diagnosis). Zbl. Bakt. Hyg. I. Abt. Orig. A 1978, 240, 16-20.

Poppe C: Salmonella enteritıdis in Canada. Int. J. Food Microbiol. 1994, 21, 1-5.

Rodrigue DC, Tauxe RV, Rowe B. International increase of Salmonella enteritidis. A new pandemic? Epıdemiol. Infect. 1990, 105, 21-27.

Schoen JL, Glass KA, McDermott JL, Wong CL: Growth and penetration of Salmonella entertidis, Salmonella heidelberg and Salmonella typhimurium in eggs. Int. J. Food Microbiol. 1995, 24, 385-396.

Shivaprasad HL, Timoney JF, Morales S, Lucio B, Baker RC Pathogenesis of Salmonella enteritidis infection in laying chickens. I. Studies on egg transmission, clinical signs, fecal shedding and serological responses. Avıan Dis. 1990, 34, 548557.

Ward $L R$, de $S a J D H$. Rowe $B$ A phage-typing scheme for Salmonella enterittdis. Epıdemiol. Infect. 1987, 99, 291-294.

Wray $C$, Davies $R H$. Bacteriological techniques. In: World Health Organization. Guidlines on Detection and monitoring of Salmonella infected poultry flocks with particular reference to Salmonella enteritidis Report of a WHO Consultation on
Strategies for Detection and Monitoring of Salmonella infected Poultry Flocks. Gras, Austria, 1994, 34-46.

\section{Sammanfattning \\ Den första Salmonella Enteritıdis fagityp 1 infektio- nen $i$ ett kommersiellt äggproducerande hönshus $t$ Finland.}

Det första finländska Salmonella Enterittdis fagıtyp (PT1) infektionsutbrottet 1 en kommersiell äggproducerande hönsflock med 2700 fåglar har förekommit och studerades. Alla fåglar slaktades, äggen förstördes och tillträde tıll farmen förbjöds för att undvika spridandet av infektıonen. 91 äggproducerande hönor, 61 unghönor och 1062 ägg samlades för analysering. Det totala infektıonsstadiet 1 flocken var $8 \%$ koncentrerat 1 de 2 àldsta åldersgrupperna. $S$ Enterttudis PT1 isoledares från lever (5\%), äggstockar (2\%) och caecum (3\%). Av de positiva caecum proven påvisades 2 med preanrikning och 3 utan preanriknıng på Rambach-agar. 8\% av 105 samlade äggprov var positiva av vilka 2 upptäcktes endast 1 innehållet och 31 skalen vilket indicerar både oviductal och fekal kontamınerıng av äggen. Resultaten stöder användandet av en utvıdgad provtagnıngsprocedur 1 fjäderfäflockar som misstänks för humana livsmedelburna Salmonella utbrott, bestående inte enbart av faecesprov utan även prov från mıljö, organ, blod och/eller ägg.

(Recelved Aprll 17, 1996; accepted August 27, 1996)

Reprints may be obtained from: T.M.-L. Johansson, Department of Food Microbiology, National Veterinary and Food Research Institute, FIN-00231, Helsınki, Finland. E-mall. tuula.johansson@eela.fi, fax: +358 9393 1907, tel: +35893931844 . 
